＜原 著 $>$

肝癌患者に打ける血清 sialyltransferase isoenzymeの

検出とその性質に関する研究

\author{
渡辺勇四郎* 清水 昭一** 福西 康夫* \\ 宮川 正人* 岡部 和彦*
}

要 旨：健常者, 慢性関節リウマチ患者および肝細胞癌と転移性肝癌患者の血清 sialyltransferase (ST) 活性を等電点電気泳動法で分析した。血液凝固時に生ずる血小板 ST の混入を除 去した血清を Ampholine（pH 3〜10）を含む等電点カラム電気泳動法で分画し，酵素活性は asialofetuin を acceptor として測定した.

健常者の血清には pI 4.40,6.65および7.00の3つのST 活性が認められた。肝癌患者の血清 では, 肝細胞癌で pI 7.90と8.30, 転移性肝癌では pI 7.90と8.20に異常 ST isoenzyme 活性が 認められた. 慢性関節リウマチ患者の血清では pI 7.90 8.30域にST 活性は認められなかっ た.

索引用語： 肝癌 等電点カラム電気泳動 血清 sialyltransferase isoenzyme

$$
\text { シアル酸 }
$$

はじめに

Sialyltransferase (ST) (EC 2.4.99.1) は複合糖質糖 鎖末端にシアル酸を転移する酵素である，血清 ST 活 泩を測定する臨床的意義については，主に悪性腫汪患 者で報告されている1,22．しかし，炎症性疾患，特に慢 性関節リウマチ患者血清ですST 活性が悪性腫煌患者 と同様に上昇する成績が報告され ${ }^{3)}$ ，血清の ST 活性 を测定するだけでは臨床的に十分有用な酵素とは言え ない一面が残されている．血清 ST の由来臉器として

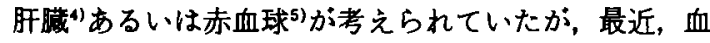
清 ST の一部が血小板に由来することが明らかにされ だ．担癌生体の血浆あるいは血清で上昇するSTに ついては肝臓由来とする報告が大勢を占めてい る ${ }^{3.7 .8)}$. また次症性疾患で上昇する血清 ST む肝荿由 来が示唆されている9 ${ }^{9-11)}$ 。これらの報告から癌患者の 血清で上昇するSTが注目されながらす，癌特異性は 低いすのとされているょうに思われる。

著者らは肝癌細胞を用いた培羞実験の成績から, ST が肝癌細胞から分泌されることを示唆する成績を得て いるが12,13)，この論文では血清を等電点カラム電気泳 動法で分画し，肝癌患者血清で上昇する ST の癌特異

・聖マリフンナ医科大学第 2 内科

** 東京大学医科学研究所制癌研究部

<受付日60年 5 月 7 日 $>$
性の有無について慢性関節リウマチ患者の血清と対比 して解析した，その際，従来の血清では血小板由来の STによる影響が大きいため，独自の方法で血小板の 影響を除いた血清6を作成して用いた。

対象ならひに方法

対象は臨床的に確定診断された癌患者29例，すなわ ち, 肝細胞癌 12 例, 胃癌および大腸癌各 5 例, 肺癌 4 例, 胆道癌 3 例である。これらの中には肝贜に転移巣 を伴った症例も含まれている．对照として健常人14名 および活動期にある慢性関節リウマチ患者 1 例であ る.

血清は 1 分血清（1'-S）と60分血清 (60'-S)を既報6) のごとく作成し，使用まで $-80^{\circ} \mathrm{C}$ に保存した， $1^{\prime}-\mathrm{S}$ と は，採血後 1 分以内にフィシャ一遠心機59型を用い， $5,000 \times$ g. 2 分間遠心し，血球成分を除去した血浆を 室温 $\left(20 \sim 25^{\circ} \mathrm{C}\right)$ に60分間放置して凝固させ，出現し たフィブリン塊を除去した血清で，血液凝固時に生ず る血小板内容物の血清中への混入を避ける目的で作成 されたものである.

血小板 lysate は以下のように作成した． 4 人の健常 者より $3.13 \%$ クンン酸ナトリウム溶液 1 容に血液 9 容 を採血し，230×g，15分間遠心し，血小板を分離，15\% の acid-citrate-dextrose-A 溶液を含むリン酸楥衝塩 化ナトリゥム液（pH 7.3）で 3 回洗浄後，得られた 
$10.8 \times 10^{8}$ 血小板を非働化 $\left(56^{\circ} \mathrm{C} ， 30\right.$ 分間）した健常者 の1'-S に浮遊し, 凍結融解を 6 回くり返し, 血小板を破 壊， $4{ }^{\circ} \mathrm{C} て ゙ 2,000 \times \mathrm{g}, 30$ 分間遠心した。得られた上清を 血小板 lysate とした.

等電点カラム電気泳動は容量 $110 \mathrm{~m} l$ の等電点電気 泳動用カラムを既報 ${ }^{14,15)}$ に従って著者らで作製して 行った. $2.5 \%$ ampholine carrier ampholyte $(\mathrm{pH}$ 3 10) (Pharmacia Fine Chemicals AB. Uppsala, Sweden)を, 10v/v\% glycerin を含 $550 \sim 0 \mathrm{w} / \mathrm{v} \%$ sucrose で linear gradient を作成し, 血清 $1.5 \mathrm{~m} l$ を力 ラムの中間位に添加した，恒温循環装置を用い，0 - $1^{\circ} \mathrm{C}$ で800V, 23時間, さらに1400V, 24時間泳動し, $2 \mathrm{~m} l /$ fraction/70秒で分画した. 血小板 lysate む同様 に泳動し，分画した。各分画の ST 活性および $\mathrm{pH}$ を直

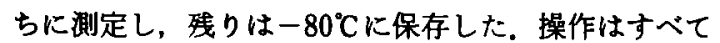
4 C Cで行った。

ST 活性の測定は CMP-[9- $\left.{ }^{3} \mathrm{H}\right]$ sialic acid $(18.9 \mathrm{Ci} /$ mmol) (New England Nuclear, Boston, Mass. USA）を基質とし, asialofetuin (ASF) を acceptor として測定した．1）血清の ST 活性は既報の)に従って 測定した. 2) 等電点カラム電気泳動分画のST 活性測 定における測定系の反応混合液は，フラクション内容 $30 \mu l, 107.4 \mathrm{mM}$ トリス塩酸楥衝液 $(\mathrm{pH} \mathrm{7.4)} 70 \mu l$ （終 涱度 $50 \mathrm{mM}$ ), $100 \mathrm{mM} \mathrm{MgCl} 210 \mu l, 100 \mathrm{mM} \mathrm{MnCl}_{2} 10$ $\mu l$, ASF $20 \mu l$ (蛋白質として約 $300 \mu \mathrm{g}$ ), 蒸留水 $7.5 \mu l$ および CMP- $\left[9 \cdot{ }^{3} \mathrm{H}\right]$ sialic acid $2.5 \mu l(0.25 \mu \mathrm{Ci})$ から

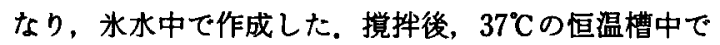
正確に30分間反応させ, $0.1 \mathrm{~N} \mathrm{HCl}$ の $1 \%$ 矮タンクス テン酸溶液 $2.0 \mathrm{~m} l$ を加充反応を停止した，以後の操作 は血清の場合と同様に行い, 酵素活性を求めた. ASF は酸水解法 ${ }^{(6)}$ で調製した。

シアル酸量はampholine怙よび sucroseを除去 し17), チオハハルヒッール法 ${ }^{18)}$ で測定した.

$\mathrm{pH}$ は Expandomatic SS-2, pH meter (Beckman, UK）を用いて $4{ }^{\circ} \mathrm{C} て ゙$ 湘定した。

$$
\text { 成 績 }
$$

\section{1. 血清 ST 活性}

従来の血清とほ注同じ60'Sに括けるST活性を Fig. 1に示した. 健常者のST 活性に比べ, 各種癌患者 の血清で明らかな高値を示し $(\mathrm{p}<0.01)$ ，肝缄に転移 果を認める症例が軽移宩のない症例に比し高值傾向を 示した。

\section{2. 等電点カラム電気泳動}

等電点カラム電気泳動法で分析した症例の中から次

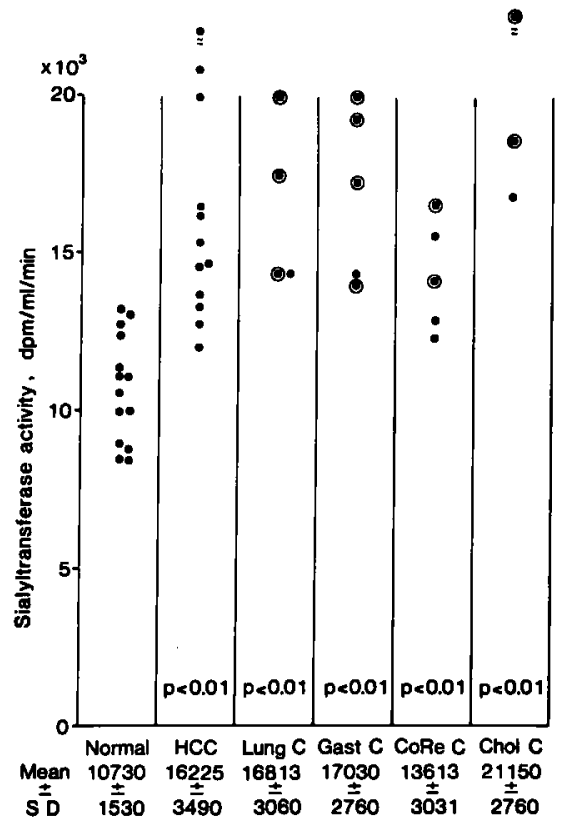

Fig. 1 Serum sialyltransferase activity is significantly higher in patients with hepatocellular carcinoma ( $\mathrm{HCC}$ ), with lung cancer (Lung C), with gastric cancer (Gast C), with colorectal cancer (CoRe $\mathrm{C}$ ) or with gall-bladder or bile ducts (Chol C) than normal healthy subjects. $\odot$ indicates the patients with liver metastasis.

の例の結果をFig. 2に示した．1）肝細胞癌患者；49 歳男性，原因不明の硬変肝の右葉に $5 \times 6 \mathrm{~cm}$ の肝細胞 癌が合併した症例であった２）肝䁍に転移巣を伴った 胃癌患者(以下，転移性肝癌とい5)；63歳女性，胃癌 と診断され，肝萜に多発性の転移巣が認められた，3） 慢性関節リウマチ(RA)患者；73歳女性, 31年前に RA と診断され，増悪と寛解をくり返し，増悪期にあった。 4）健常者；40歳男性，1 カ月前より薬物の服用はな かった。

1） $1^{\prime} \mathrm{S}$ S等電点電気泳動：健常者では等電点 (pI) $4.40,6.65 お よ ひ ゙ 7.00 k \mathrm{ST}$ 活性が得られた。肝細胞癌 (HCC) では pI 4.40,5.00,6.65,7.90と8.30k ST isoenzyme 活性が存在した。転移性肝癌では pI 4.40, $5.35,6.50,7.15$ および7.80 8.20に ST isoenzyme 活 性を認めた。 RA では pI 4.20, 4.65, 5.10, 5.45, 6.20 および6.80にST 活性を認めた。

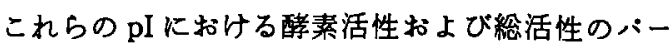
セント活性率を Table 1に示した。すなわち，健常者 では pI 6.65に総活性の56.7\%を占める最大活性が認 

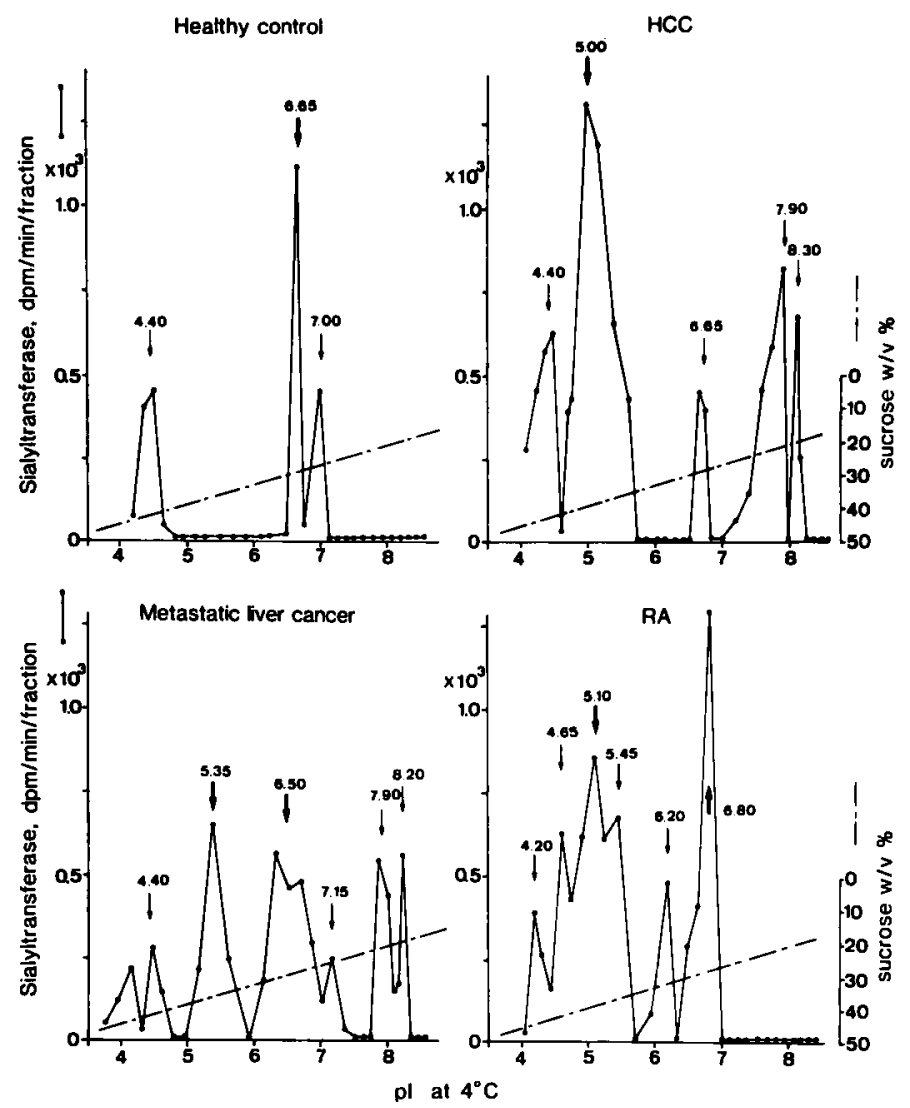

Fig. $21.5 \mathrm{~m} l$ of human serum ( $\left.1^{\prime}-\mathrm{S}\right)$ was applied to a column (capacity of 110 $\mathrm{m} l$ ) of $50-0 \mathrm{w} / \mathrm{v} \%$ sucrose gradient containing $2.5 \%$ ampholine carrier ampholyte ( $\mathrm{pH} \mathrm{3} \mathrm{10)} \mathrm{and} \mathrm{10v/v \%} \mathrm{glycerin,} \mathrm{and} \mathrm{was} \mathrm{developed} \mathrm{as} \mathrm{described} \mathrm{under}$ "Materials and Methods". Sialyltransferase activity was determined using CMP- $\left(9-{ }^{3} \mathrm{H}\right)$ sialic acid as substrate and asialofetuin as acceptor. The abnormal sialyltransferase isoenzyme activity was observed at the $\mathrm{pH}$ range $7.80 \sim 8.30$ in serum from patients with hepatocellular carcinoma (HCC) and with metastatic liver cancer.

められた。肝細胞癌では pI 5.00に最大活性（32.7\%） をすち pI $7.90(20.3 \%)$ と8.30 (20.3\%) にも高い活 性を示した。転移性訮癌では最大活性が $\mathrm{pI} 5.35$ (20.9\%)にあり， pI $7.90(17.6 \%)$ と8.20(18.3\%) に肝細胞癌と同様にST isoenzyme 活性を認めたが, pI 5.00にはST 活性が存在しなかった. RAでは pI 6.80に最大活性（35.5\%）を示したが, pI 7.90〜8.30 域にはST 活性が諗められなかった。

以上, 1'-S を用いて行った等電点電気泳動の結果, 肝 細胞癌および転移性肝癌患者では pI 7.90〜8.30に ST isoenzyme 活性が存在し，肝細胞癌癌患者に存在 する pI 5.00の ST isoenzyme 活性が転移性肝癌患者
には認められないことが明らかとなった。

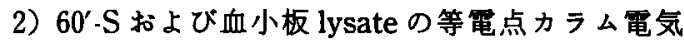
泳動：60'-S は採血後60分間室温に放置し,十分凝固さ せてから遠心して得た血清である.Table 1に示すご とく，健常者の60'-S では pI 5.80と6.55に主な ST 活 性が存在し, pI 6.55に総活性の53.8\%が存在した. 肝 細胞癌では pI 6.60 (48.2\%) と7.70（31.4\%）にST 活性が存在した。この pI 7.70の ST 活性は異常 ST isoenzyme 活性と考古られた。転移性肝癌では pI 6.55 に52.3\%の活性を認めた。次に慢性関節リウマチでは pl 6.20に主活性（56.7\%）を示した。

以上のように60'Sでは各疾患とも健常人で最大活 
Table 1 Characterizations of sialyltransferase activity by isoelectric focusing.

\begin{tabular}{|c|c|c|c|}
\hline Serum & pI & $\begin{array}{l}\text { ST activity } \\
\mathrm{dpm} / \mathrm{min} / \mathrm{ml}\end{array}$ & rate of total activity \\
\hline Normal $1^{\prime}-\mathrm{s}$ & $\begin{array}{l}4.40 \\
6.65 \\
7.00\end{array}$ & $\begin{array}{r}406.4 \\
1128.3 \\
455.2\end{array}$ & $\begin{array}{l}20.4 \\
56.7 \\
22.9\end{array}$ \\
\hline $60^{\circ}-\mathrm{s}$ & $\begin{array}{l}4.35 \\
5.80 \\
6.55 \\
7.90\end{array}$ & $\begin{array}{r}686.7 \\
1405.7 \\
2874.7 \\
373.8\end{array}$ & $\begin{array}{r}12.9 \\
26.3 \\
53.8 \\
7.0\end{array}$ \\
\hline H C C I'- s & $\begin{array}{l}4.40 \\
5.00 \\
6.65 \\
7.90 \\
8.30\end{array}$ & $\begin{array}{r}627.8 \\
1317.6 \\
447.1 \\
818.4 \\
819.8\end{array}$ & $\begin{array}{l}15.6 \\
32.7 \\
11.1 \\
20.3 \\
20.3\end{array}$ \\
\hline $60^{\prime}-s$ & $\begin{array}{l}4.40 \\
5.60 \\
6.60 \\
7.70\end{array}$ & $\begin{array}{r}493.8 \\
689.0 \\
2784.7 \\
1815.8\end{array}$ & $\begin{array}{r}8.5 \\
11.9 \\
48.2 \\
31.4\end{array}$ \\
\hline \multicolumn{2}{|c|}{$\begin{array}{l}\text { Metastatic liver } \\
\text { cancer 1'- S } 4.15 \\
4.40 \\
5.35 \\
6.50 \\
7.15 \\
7.90 \\
8.20\end{array}$} & $\begin{array}{l}236.2 \\
285.2 \\
643.4 \\
558.6 \\
250.0 \\
541.8 \\
565.3\end{array}$ & $\begin{array}{r}7.7 \\
9.3 \\
20.9 \\
18.1 \\
8.1 \\
17.6 \\
18.3\end{array}$ \\
\hline $60^{\prime}-s$ & $\begin{array}{l}4.35 \\
4.60 \\
5.15 \\
6.55\end{array}$ & $\begin{array}{r}1013.9 \\
700.6 \\
787.9 \\
2737.6\end{array}$ & $\begin{array}{l}19.3 \\
13.4 \\
15.0 \\
52.3\end{array}$ \\
\hline RA $1^{\prime}-\mathbf{S}$ & $\begin{array}{l}4.20 \\
4.65 \\
5.10 \\
6.20 \\
6.80\end{array}$ & $\begin{array}{r}390.0 \\
624.7 \\
859.8 \\
488.5 \\
1300.8\end{array}$ & $\begin{array}{l}10.6 \\
17.1 \\
23.5 \\
13.3 \\
35.5\end{array}$ \\
\hline $60^{\prime}-5$ & $\begin{array}{l}4.95 \\
5.35 \\
6.20 \\
6.80 \\
7.30\end{array}$ & $\begin{array}{r}940.4 \\
1546.8 \\
4768.1 \\
432.7 \\
727.5\end{array}$ & $\begin{array}{r}11.2 \\
18.4 \\
56.7 \\
5.1 \\
8.6\end{array}$ \\
\hline \multicolumn{4}{|l|}{ Platelet lysate } \\
\hline & $\begin{array}{l}6.20 \\
7.85 \\
8.10\end{array}$ & $\begin{array}{r}826.3 \\
145.2 \\
53.3\end{array}$ & $\begin{array}{r}80.6 \\
14.2 \\
5.2\end{array}$ \\
\hline
\end{tabular}

性を示す $\mathrm{pI}$ 6.55とはぼ同じ $\mathrm{pI}$ に最大醅素活性を示 し, 肝細胞癌の pI 7.70の他には異常な ST isoenzyme 活性は認められなかった. 次に血小板 lysate の等電点 電気泳動では総 ST 活性の $80.6 \%$ pI 6.20に存在し た。このことから健常人打よび各疾患の60․Sで認めら れた最大 ST 活性を示す $\mathrm{pI}$ の ST は血小板 ST の混 入により強い修飾を受けた結果として生したものと考 えられた。

3） 1'-Sの等電点カラム電気泳動後測定したシフル 酸は, 健常人では pI 3.20 6.40, 肝細胞癌および転移 性肝癌ではそれぞれ pI 3.80〜5.50および pI 3.40 6.10の pI 領域で，また慢性関節りウマチでは pl 3.30 6.70の領域で測定された。この成績から肝細 胞癌および転移性肝癌の1'-Sで認められた $\mathrm{pI}$ 7.90 8.30の ST isoenzyme はシアル酸をすたない isoemzymeであることが示唆された。

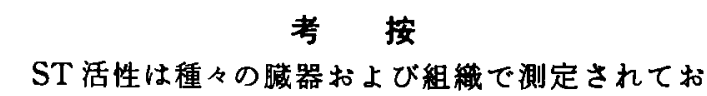
ク, 血清中にも可溶型として存在しているか，血清 ST の生理的意義はまだ明らかにされていない，癌患者や 担癌動物で血清 ST 活性が上昇し，上昇した䣼素活性

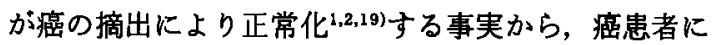
拈けるST の特異性が示唆されていた.しかし, 本酵素 の癌特異性はまだ明らかになっていない。

血小板にも高いST 活性が存在し，血清作製時にこ の酔素が血小板から血清中に多量に混入する゙ため に, 血清のST 活性値から病態解析を行った場合に, 従 来の血清では知患における特徽が明らかでなかった。

著者らは循環血浆に近い血清として血球，特に血小板 の影響を除いた血清 $\left(1^{\prime}-\mathrm{S}\right)$ を用いたか，この場合には 本論文のように疾患の特異性を明瞭にすることができ た。

従来, 癌細胞は血浆蛋白を分泌しないと考えられて いた201.しかし, 腹水肝癌細胞株, MH 134拈よび Chang 肝細胞を48時間培咯した結果，ST 活性が培盖 液では癌細胞で高値を示し，培養細胞では Chang 肝細 胞の方が高値を示した著者らの成績から，癌細胞も STを分泌すると考えられだ13).

蛋白質や䣼素の分析に等電点電気泳動の技術を用い る機会が多くなっているが，蛋白質の分離と異なり酵 素の場合には操作中に起る酵素活性の失活を小さくす ることが重要となる，等電点電気泳動中あるいは他の 拯作中に ST 活性の失活をできるたけ小さくするため に著者らは, sucrose gradient 中に10V/V\%の glycerin 加之, 電気泳動中は恒温循環装置を用いてカラム の温度を 0ー $1^{\circ} \mathrm{C}$ に保った。 また, 電気泳動終了後, 力 ラム内は $\mathrm{pH} 2.80$ から pH 11.50まで linear gradient に分画されていたか，ST 活性測定系の $\mathrm{pH}$ を至適 $\mathrm{pH}$ である7.4にするために測定系のトリス塩酸楥衝液の

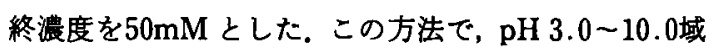
の分画は $\mathrm{pH} 7.4$ に補正された。緩衝液の濃度を $50 \mathrm{mM}$ に増したことによる醭素活性への影響は認められな かった。

糖蛋白質の等電点 $(\mathrm{pl})$ は主として糖鎖のシアル酸量 と蛋白質の構成了ミノ酸によって決まる。健常者, 肝 細胞癌, 転移性肝癌および慢性関節リウマチ患者の血 清では, いずれも $\mathrm{pI} 3.20 〜 6.70 の$ 領域内でシフル酸が チオバルビッル酸法で検出可能であった. pI はシフル 酸の有無だけで決まるるのではないが，肝細胞癌およ び転移性肝癌患者の血清で特異的に認められた pI 
7.90 8.30の異常 ST isoemzyme はシアル酸をむた ないSTであることが示唆された。

\section{結語}

健常者, 慢性関節リウマチ患者扰よび肝細胞癌と転 移性肝癌患者から，血清作成時に生ずる血小板 ST の 混入を除去した血清を分離し，等電点カラム電気泳動 法（pH 3 10）を用いてこれらの血清を分析した。そ の結果, 肝細胞癌患者では pI 7.90と8.30に, また転移 性肝癌患者ではpI 7.90 と8.20k異常 ST isoenzyme 活性が存在した，健常者および僈性関節りウマチ患者 の血清では pI 7.90〜8.30域にST 活性は認められな かった.

\section{文献}

1) Henderson M, Kessel D: Alterations in plasma sialytransferase levels in patients with neoplastic diseases. Cancer $39:$ 1129-1134, 1977

2) Ganzinger U, Deutsch E : Serum sialyltransferase levels as a parameter in the diagnosis and follow-up of gastrointestinal tumors. Cancer Res $40: 1300-1304,1980$

3) Kessel D, Allen J : Elevated plasma sialytransferase in the cancer patient. Cancer Res $35: 670$ $-672,1975$

4) Mookerjea S, Michaels MA, Hudgin RL, et al : The levels of nucleotide-sugar: glycoprotein sialyl-and $\mathrm{N}$-acetylglucosaminyltransferases in normal and pathological human sera. Can J Biochem 50 : 738-740, 1972

5) Kim YS, Perdomo J, Bella A, et al : Properties of a CMP-N-acetylneuraminic acid: glycoprotein sialyltransferase in human serum and erythrocyte membranes. Biochim Biophys Acta $244: 505-512,1971$

6）渡辺勇四郎, 岡部和彦: 血清シフリルトランス フェラーゼ活性の剧定一肝垁患における変動を中 心に一。臨床病理 特集54号：188-196，1983

7) Evans IM, Hilf R, Murphy M, et al : Correlation of serum, tumor, and liver serum glycoprotein: $\mathrm{N}$-acetylneuraminic acid transferase activity with growth of the R3230AC mammary tumor in rats and relationship of the serum activity to tumor burden. Cancer Res $40: 3103$ $-3111,1980$

8) Dairaku K, Miyagi T, Wakui A, et al: Increase in serum sialyltransferase in tumor-bear. ing rats : the origin and nature of the increased enzyme. Gann 74 : 656-662, 1983

9) Fraser IH, Coolbear T, Sarkar M, et al : Increase of sialyltransferase activity in the serum and liver of inflamed rats. Biochim Biophys Acta $799: 102-105,1984$

10) Canonico PG, Little JS, Powanda MC, et al: Elevated glycosyltransferase activities in infected or traumatized hosts: Nonspecific response to inflammation. Infect Immun $29: 114$ $-118,1980$

11) Kaplan HA, Woloski BMRNJ, Hellman M, et al: Studies on the effect of inflammation on rat liver and serum sialyltransferase. Evidence that inflammation cause of Gal $\beta 1 \rightarrow$ $4 \mathrm{GlcNAc} \alpha 2 \rightarrow 6$ sialyltransferase from liver. J Biol Chem 258 : 11505-11509, 1983

12) Watanabe $Y$, Shimizu $S$, Kamogawa $A$, et al : Serum sialyltransferase activity in cases of cancer of the liver. Proc 41st Annu Meet Jpn Cancer Assoc, 283, 1982

13）秋山新二郎, 渡辺勇四郎, 清水昭一, 他：肝癌患者 における血清 sialyltransferase 活性の上㫒機序 について。肝臟 26(5):613-617, 1985

14) Svensson H: Isoelectric fraction, analysis, and characterization of ampholytes in natural $\mathrm{pH}$ gradients. III. Description of apparatus for electrolysis in columns stabilized by density gradients and direct determination of isoelectric points. Arch Biochem Biophys Suppl $1: 132-138,1962$

15) Vesterberg 0 , Wadström $T$, Vesterberg $K$, et al: Studies on extracellular proteins from Staphylococcus aureus. I. separation and characterization of enzymes and toxins by isoelectric focusing. Biochim Biophys Acta 133 : 435-445, 1967

16) Spiro GR: Studies of fetuin, a glycoprotein of fetal serum. I. Isolation, chemical composition, and physicochemical properties. J Biol Chem 235 : 2860-2869, 1960

17) Bensadoun A, Weinstein $D$ : Assay of proteins in the presence of interfering materials. Anal Biochem $70: 241-250,1976$

18) Warren $L$ : The thiobarbituric acid assay of sialic acids. J Biol Chem 234 : 1971-1975, 1959 
19) Kondo Y, Sato K, Ueyama, et al: Serum sialyltranferase and liver catalase activity in cachectic nude mice bearing a human malignant melanoma. Cancer Res 41: 2912 $-2916,1981$
20) Schreiber G, Boutwell RK, Potter VR, et al : Lack of secretion of serum protein by transplanted rat hepatomas. Cancer Res 26: 2357 $-2361,1966$

\title{
Serum sialyltransferase isoenzyme activities in patients with liver cancer
}

\author{
Yushiro Watanabe*, Shoichi SHIMIZU**, Yasuo FukUNISHI*, \\ Masato MIYAGAWA* and Kazuhiko OKABE*
}

Serum sialyltransferase (ST) activity has been studied using isoelectric focusing chromatography in normal subjects, in patients with rheumatoid arthritis, and in patients with liver cancers (hepatocellular carcinoma and liver metastasis).

The serum which was avoided the contamination of platelet-ST was applied to an isoelectric focusing column containing ampholine (pH 3-10) and the fractions were assayed using asialofetuin as the sialic acid acceptor. Three peaks of ST activity were found in serum from normal subjects at pI 4.40,6.65 and 7.00. In serum from patients with liver cancer, we found abnormal ST isoenzyme activity at pI 7.90 and 8.30 in hepatocellular carcinoma and pI 7.90 and 8.20 in metastatic liver cancer. These abnormal ST isoenzymes have possibly not sialic acids in their structure. And we did not found the ST activity in sera from patients with rheumatoid arthritis at this $\mathrm{pI}$ range.

* Second Department of Internal Medicine, St Marianna University School of Medicine, Kawasaki (Kanagawa)

** Institute of Medical Science the University of Tokyo, Department of Oncology Research (Tokyo) 